Check for updates

Cite this: RSC Adv., 2018, 8, 5013

Received 25th December 2017 Accepted 23rd January 2018

DOI: 10.1039/c7ra13628e

rsc.li/rsc-advances

\section{Application of pyrite and chalcopyrite as sensor electrode for amperometric detection and measurement of hydrogen peroxide}

\begin{abstract}
Y. Wang, (D) ${ }^{a}$ K. J. Zhao, ${ }^{a}$ D. P. Tao, ${ }^{\text {tb }}$ F. G. Zhai, ${ }^{\text {a H. B. Yang }}{ }^{a}$ and Z. Q. Zhang (D) *a
The sensing performance of solid-state amperometric sensors based on natural sulfide minerals, i.e., pyrite and chalcopyrite, has been characterized for the detection and measurement of hydrogen peroxide $\left(\mathrm{H}_{2} \mathrm{O}_{2}\right)$ in aqueous medium. The sensors showed a wide linear relationship range between response current and the concentration of $\mathrm{H}_{2} \mathrm{O}_{2}$ from $1.0 \times 10^{-5} \mathrm{~mol} \mathrm{~L}^{-1}$ to $1.0 \times 10^{-2} \mathrm{~mol} \mathrm{~L}{ }^{-1}$ and $1.0 \times 10^{-4} \mathrm{~mol} \mathrm{~L}^{-1}$ to 3.0 $\times 10^{-2} \mathrm{~mol} \mathrm{~L}^{-1}$ for pyrite and chalcopyrite, respectively. The limit of detection (LOD) was as low as $8.6 \times$ $10^{-6} \mathrm{~mol} \mathrm{~L}^{-1}$ and $5.2 \times 10^{-5} \mathrm{~mol} \mathrm{~L}^{-1}(\mathrm{~S} / \mathrm{N}=3)$, respectively. The electrodes exhibited great sensitivity, repeatability and short response time (less than $5 \mathrm{~s}$ ). The results show that pyrite and chalcopyrite can be used as a natural, low cost, reliable and sensitive sensor for hydrogen peroxide detection, creating a new and high value application for the sulfide minerals.
\end{abstract}

\section{Introduction}

Hydrogen peroxide $\left(\mathrm{H}_{2} \mathrm{O}_{2}\right)$ is widely present in nature, particularly in waterways and various life systems. It is not only a product of the reactions catalyzed by various oxidase enzymes, but also an essential compound in industrial, clinical, pharmaceutical and environmental analyses. ${ }^{1,2}$ The sensitive, accurate, and low-cost determination of $\mathrm{H}_{2} \mathrm{O}_{2}$ is essential for industrial processes and clinical research. There are a number of methods for $\mathrm{H}_{2} \mathrm{O}_{2}$ detection and measurement, including spectrophotometry, ${ }^{3}$ titrimetry, ${ }^{4}$ X-ray absorption, ${ }^{5}$ chemiluminescence $^{6}$ and fluorometric methods. ${ }^{7}$ These methods usually require expensive equipment and reagents, complicated and time-consuming procedures and skillful operators. Therefore, the electrochemical technique for $\mathrm{H}_{2} \mathrm{O}_{2}$ detection becomes one of the most attractive alternatives due to its simplicity, high sensitivity and selectivity. ${ }^{\mathbf{8 - 1 1}}$ It has proved to be an effective and simple technique for $\mathrm{H}_{2} \mathrm{O}_{2}$ determination. ${ }^{\mathbf{1 2}}$

Conventional electrochemical technique for $\mathrm{H}_{2} \mathrm{O}_{2}$ detection and measurements is usually carried out using enzyme immobilization modified electrodes, which have gained great interest due to its unique advantage in sensitivity and selectivity. ${ }^{\mathbf{1 3 , 1 4}}$ However, the enzyme-based sensors often lack of acceptable stability due to the inherent characteristics of enzymes the activity of which can readily be affected by temperature, $\mathrm{pH}$,

${ }^{a}$ School of Chemical Engineering, University of Science and Technology Liaoning, 185 Qianshan Middle Road, High-tech zone, Anshan, Liaoning, 114501, China. E-mail: zhangzhiqiang@ustl.edu.cn

${ }^{b}$ School of Mining Engineering, University of Science and Technology Liaoning, 185 Qianshan Middle Road, High-tech zone, Anshan, Liaoning, 114501, China. E-mail: dptao@qq.com humidity, and toxic chemicals. ${ }^{\mathbf{1 5 , 1 6}}$ Therefore, much attention has recently been paid to the development of non-enzymatic electrochemical $\mathrm{H}_{2} \mathrm{O}_{2}$ sensors for their simplicity, high reliability and sensitivity and low cost. ${ }^{17-19}$ Numerous functional materials were used for the non-enzymatic sensing of $\mathrm{H}_{2} \mathrm{O}_{2}$, including nanostructured materials, ${ }^{20-22}$ ionic liquid, ${ }^{23}$ polymer, ${ }^{24}$ sol-gel $^{25}$ and ceramic matrix. ${ }^{26,27}$ In order to develop a better technique for detection and measurement of $\mathrm{H}_{2} \mathrm{O}_{2}$, electrodes made of natural pyrite and chalcopyrite have been investigated in this study for their feasibility to function as a sensor for $\mathrm{H}_{2} \mathrm{O}_{2}$ in aqueous medium.

Pyrite and chalcopyrite represent the Earth's most abundant and widespread sulfide minerals. Pyrite, with the formula of $\mathrm{FeS}_{2}$, is a $\mathrm{Fe}(\mathrm{II})$ polysulfide with a cubic NaCl-type crystalline structure. It is the most thermodynamically stable iron sulfide found in the nature. Over the past decades, the electrochemistry of pyrite has been studied extensively. ${ }^{28-31}$ As the most abundant copper mineral, chalcopyrite $\left(\mathrm{CuFeS}_{2}\right)$ is the most economically important copper resource and is always found in association with pyrite. The selective separation of chalcopyrite from pyrite is very difficult because of several electrochemical interactions that occur at the surface of minerals during grinding. ${ }^{32}$ New applications of pyrite and chalcopyrite are of great importance. Due to their excellent characteristics such as semiconductivity, non-toxicity, and availability in the nature pyrite and chalcopyrite have recently been used in various electrochemical applications in the form of solid state sensor materials. ${ }^{33-36}$

In this study, the natural minerals (pyrite and chalcopyrite) were used as the working electrode to detect the $\mathrm{H}_{2} \mathrm{O}_{2}$ in aqueous solution. The main purpose of this study was to further explore analytical applications of pyrite and chalcopyrite electrodes, with a focus on developing an inexpensive, rapid and 
convenient method for the determination of biologically important compound, $\mathrm{H}_{2} \mathrm{O}_{2}$. It has been found that under the optimum operational conditions, the pyrite and chalcopyrite based sensors showed good sensitivity, rapid response time and excellent operational stability for the detection and measurement of hydrogen peroxide. Compared with traditional nonenzyme biosensor that works in alkaline solution, the pyrite and chalcopyrite sensors can detect $\mathrm{H}_{2} \mathrm{O}_{2}$ not only in alkaline solution, but also in acidic and neutral environment with Britton-Robinson buffer, which is an amazing feature for a new analytical sensor developed from different material. This unique characteristic of mineral sensors will lead to more extensive applications of $\mathrm{H}_{2} \mathrm{O}_{2}$ sensors in various industries.

\section{Experimental}

\section{Reagents and materials}

The experiments were carried out with samples of natural pyrite and chalcopyrite (from Shanxi province, China) without further purification. The pyrite and chalcopyrite samples were first cut into about $5 \mathrm{~mm} \times 5 \mathrm{~mm} \times 5 \mathrm{~mm}$ in size in the university laboratory. The processed sulfide mineral samples were then sent to Tianjin AIDAhengsheng Science-Technology Development Co., Ltd. to fabricate the sensor electrodes. The fabrication process is described briefly as follows: the column-shaped mineral electrode sample was covered by Teflon with only two ends exposed to air. One end was connected to a copper wire and the other end was inserted into the solution to detect $\mathrm{H}_{2} \mathrm{O}_{2}$. The copper wire was connected to the electrochemical analyzer. The working area was $0.20 \mathrm{~cm}^{2}$ for both pyrite and chalcopyrite electrodes. Prior to each experiment, the working surface of an electrode was polished using alumina powder $(0.05 \mu \mathrm{m})$ for $30 \mathrm{~s}$ to obtain a shiny new surface, rinsed with deionized water and dried at the room temperature.

Uric acid (UA), glucose, fructose, sodium hydroxide $(\mathrm{NaOH})$, phosphoric acid, glacial acetic acid, boric acid and hydrogen peroxide $\left(\mathrm{H}_{2} \mathrm{O}_{2}\right)$ were purchased from Sinopharm Chemical Reagent Co., Ltd. A 0.1 M Britton-Robinson buffer (BR, prepared by mixing phosphoric acid, glacial acetic acid and boric acid) was used to prepare electrolyte for the acidic solution. The neutral and alkaline solutions were adjusted by blending the mixed acid and $\mathrm{NaOH}$. All chemicals were of analytical grade and were used without further purification.

\section{Apparatus}

The morphology of the minerals was observed using the fieldemission scanning electron microscope (FE-SEM) (इIGMA-HD, ZEISS). The chemical components of pyrite and chalcopyrite were obtained using an X-ray fluorescence analyzer EDX 8300 manufactured by Suzhou Precision Instrument Co., Ltd. Electrochemical measurements were performed with a CHI 750D workstation (Shanghai Chenhua, China). A conventional three electrode system with pyrite or chalcopyrite as working electrode, a thin Pt wire as counter electrode and $\mathrm{Ag} / \mathrm{AgCl}$ (sat. $\mathrm{KCl}$ ) as reference electrode was employed in this study. All measurements were performed in air at room temperature of approximately $20^{\circ} \mathrm{C}$.

\section{Results and discussion}

\section{Characterization of pyrite and chalcopyrite}

Field emission scanning electron micrograph (FE-SEM) was used to investigate the structure and morphology of pyrite electrode surface (A), chalcopyrite electrode surface (B), pyrite middle section (C) and chalcopyrite middle section (D) as shown in Fig. 1. The black parts (II, V, VI, VIII) in Fig. 1 are attributed to the impurities. Since chalcopyrite always coexists with pyrite in natural minerals, it is not unusual to observe the dark grey parts (I, IV, VII, IX) which represent the pyrite mineral. The light grey (part III, X) is the morphology of chalcopyrite. The SEM characterization was performed with the middle section of mineral sample after fracture and the results is in good agreement with pyrite and chalcopyrite electrode surfaces, implying the uniformity in composition of the minerals along the electrode length. The FE-SEM energy spectra showed that the $\mathrm{FeS}_{2}$ content of pyrite and chalcopyrite are $91.2 \%$ and $63.6 \%$, respectively. Comparing the SEM image and energy spectrum indicates that half of chalcopyrite mineral is composed of pyrite.

The phase characteristics and structures of pyrite and chalcopyrite were identified from the X-ray diffraction (XRD) patterns shown in Fig. 2. The broad diffraction peaks observed in Fig. 2A can be assigned to $\mathrm{FeS}_{2}$ structure which is the main content of pyrite sample. $\mathrm{FeS}_{2}$ is also a major component in Fig. 2B, confirming pyrite is closely associated with chalcopyrite. The five diffraction peaks observed with $2 \theta$ values of 29.44, 49.11, 59.06, 79.06 and 81.52 are attributed to $\mathrm{CuFeS}_{2}$. Fig. 2 suggests both pyrite and chalcopyrite contain impurities such as $\mathrm{SiO}_{2}$ and $\mathrm{ZnS}$ which is in accordance with the XRF data shown below.

To quantify the components of pyrite and chalcopyrite minerals, X-ray fluorescence (XRF) analysis was carried out and the results are shown in Table 1 . The impurities in pyrite can introduce significant variations in its bulk semi-conducting properties which can directly affect the reactivity of pyrite

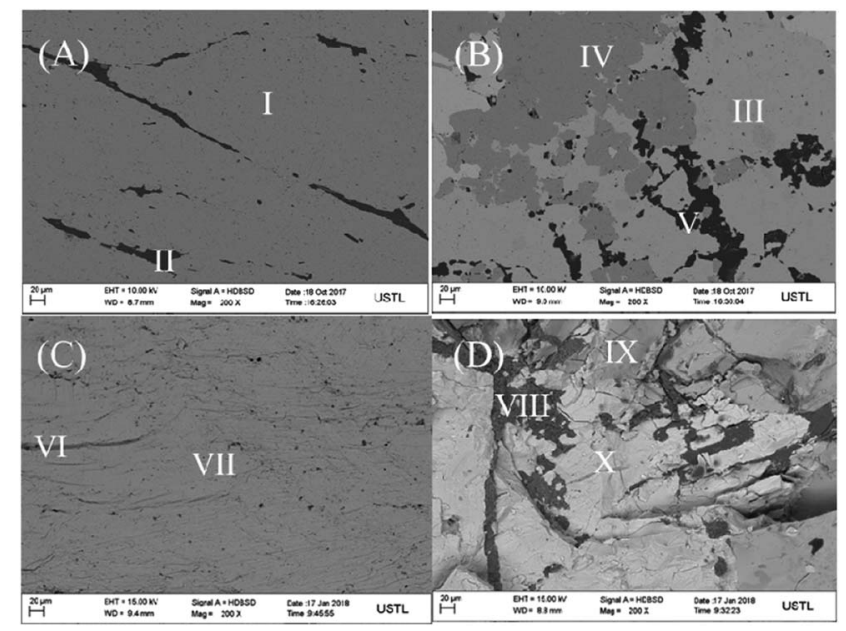

Fig. 1 The SEM images of pyrite electrode surface (A), chalcopyrite electrode surface (B), pyrite middle section (C) and chalcopyrite middle section (D) 

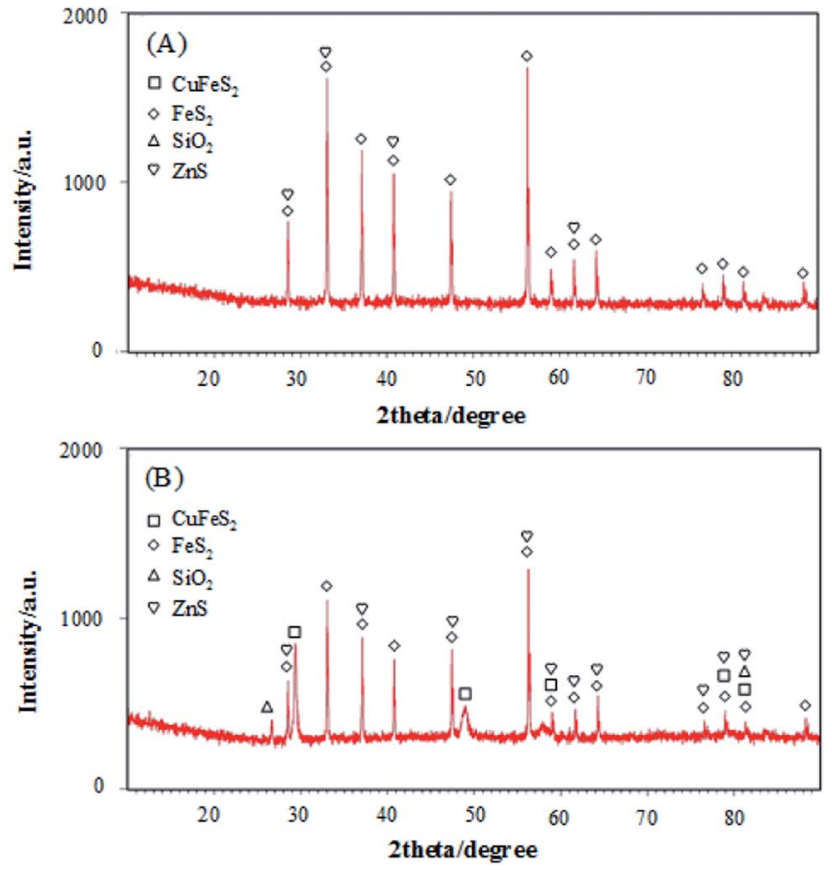

Fig. 2 The XRD patterns of pyrite (a) and chalcopyrite (b).

Table 1 XRF analysis of pyrite and chalcopyrite powder

\begin{tabular}{llrrl}
\hline Mineral & $\mathrm{Fe}$ & $\mathrm{Cu}$ & $\mathrm{S}$ & Impurities \\
\hline Pyrite & 33.05 & 0.11 & 10.95 & 10.47 \\
Chalcopyrite & 22.16 & 11.72 & 8.20 & 10.45
\end{tabular}

surfaces. ${ }^{37}$ Table 1 shows that the powder pyrite sample contained a very low content of $\mathrm{Cu}$ element. Thus, iron sulfide $\mathrm{FeS}_{2}$ plays a dominant role in the detection of $\mathrm{H}_{2} \mathrm{O}_{2}$. The XRF data obtained with pyrite powder showed a lower purity than that of the FE-SEM energy spectra. It is believed that the purity of electrode surface used to detect $\mathrm{H}_{2} \mathrm{O}_{2}$ was enhanced to some extent by polishing and soaking in alkaline solutions.

\section{Electrocatalytic performance of $\mathrm{H}_{2} \mathrm{O}_{2}$ on pyrite and chalcopyrite}

The CVs of the pyrite and chalcopyrite with and without $\mathrm{H}_{2} \mathrm{O}_{2}$ in $0.1 \mathrm{M} \mathrm{NaOH}$ are shown in Fig. $3 \mathrm{~A}$ and $\mathrm{B}$. The reduction peak current increased with increasing the concentration of $\mathrm{H}_{2} \mathrm{O}_{2}$,
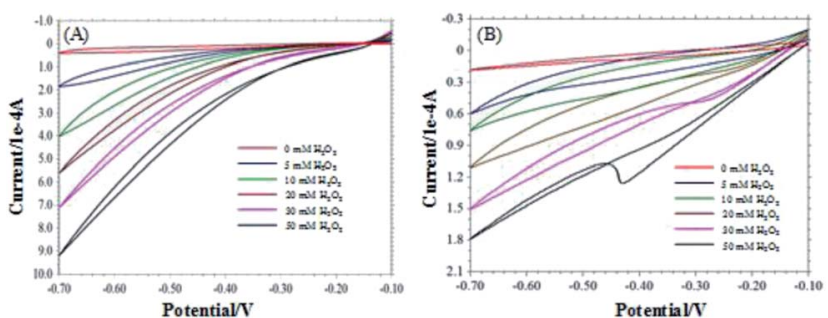

Fig. $3 \mathrm{CVs}$ of pyrite (A) and chalcopyrite (B) in the different concentrations of $\mathrm{H}_{2} \mathrm{O}_{2}(0-50 \mathrm{mM})$. indicating the pyrite and chalcopyrite based sensors have good sensitivity for $\mathrm{H}_{2} \mathrm{O}_{2}$. However, the sensitivity of chalcopyrite is lower than that of pyrite. The large content of impurity in chalcopyrite resulted in the irregular CV curves and lower sensitivity.

Fig. 4A shows the typical current plot for the pyrite based sensor on successive additions of $5 \mathrm{mM} \mathrm{H}_{2} \mathrm{O}_{2}$ in $25 \mathrm{mM} \mathrm{NaOH}$ under stirring at the working potential of $-0.2 \mathrm{~V}$. Fig. $4 \mathrm{~B}$ is the typical current response for chalcopyrite electrode on successive additions of $5 \mathrm{mM} \mathrm{H}_{2} \mathrm{O}_{2}$ in $25 \mathrm{mM} \mathrm{NaOH}$ at the working potential of $-0.4 \mathrm{~V}$. Well-defined current responses for $\mathrm{H}_{2} \mathrm{O}_{2}$ were obtained at both pyrite and chalcopyrite electrodes. The pyrite sensor exhibited good repeatability with a relative standard deviation (RSD) of $4.2 \%$ for 10 successive measurements. The chalcopyrite sensor also showed rather good repeatability with a RSD of $5.3 \%$ for 8 incremental additions of $\mathrm{H}_{2} \mathrm{O}_{2}$. These results are better than certain $\mathrm{H}_{2} \mathrm{O}_{2}$ biosensors that undergo the complicated fabrication procedures. ${ }^{39,40}$ The response time is one of the most important parameters for describing sensor characteristics. ${ }^{41}$ The response current achieved the steady state in less than 3 seconds for pyrite and within 4 seconds for chalcopyrite, representing rapid response rates for natural minerals as compared with other materials such as ceramic carbon composite, ${ }^{42}$ carbon felt, ${ }^{11}$ glassy carbon, ${ }^{43}$ iron nanoparticles, ${ }^{44}$ and carbon nanotubes. ${ }^{45}$ Based on the above results it is reasonable to conclude that pyrite and chalcopyrite are excellent natural mineral sensors for detection and measurements of $\mathrm{H}_{2} \mathrm{O}_{2}$.

The same component $\mathrm{FeS}_{2}$ exists in both pyrite and chalcopyrite minerals. It is speculated that the electro-catalytic reaction happened between $\mathrm{FeS}_{2}$ and $\mathrm{H}_{2} \mathrm{O}_{2}$ in the two electrodes. The results in Fig. 5C and D indicate that even in acidic and neutral solution, pyrite and chalcopyrite still can detect $\mathrm{H}_{2} \mathrm{O}_{2}$ in the negative potential range. This suggests hydroxyl group $(\mathrm{OH}-)$ is not essential for the electro-catalytic reaction. $\mathrm{FeS}_{2}$ was oxidized by $\mathrm{H}_{2} \mathrm{O}_{2}$ to produce $\mathrm{Fe}^{3+}$ and $\mathrm{S}^{0}$. Previous studies have found that $\mathrm{Fe}^{3+}$ can be reduced to $\mathrm{Fe}^{2+}$ at $-0.4 \mathrm{~V}^{30}$ and the reduction of $\mathrm{S}^{0}$ to $\mathrm{HS}^{-}$happened at $-0.6 \mathrm{~V}^{38}$ Fig. 3 reveals that the reduction current increased with decreasing the applied potential, as more elemental sulphur was reduced to $\mathrm{HS}^{-}$at lower potentials.

In order to identify the optimum conditions for pyrite and chalcopyrite electrodes used for detection of $\mathrm{H}_{2} \mathrm{O}_{2}$, the applied
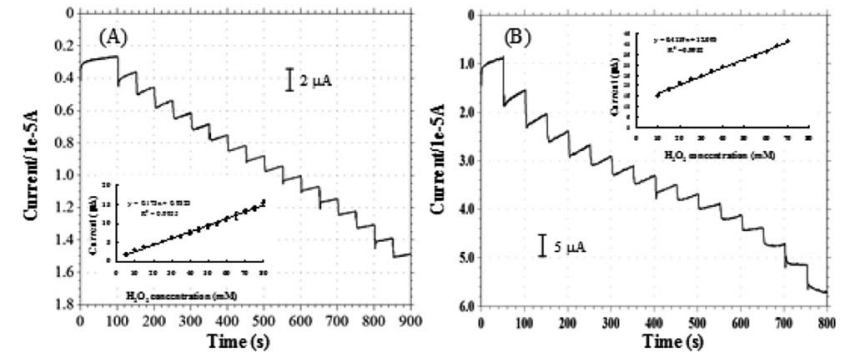

Fig. 4 Amperometric responses of $\mathrm{H}_{2} \mathrm{O}_{2}$ on pyrite ((A), applied potential $\left.-0.2 \mathrm{~V},\left[\mathrm{H}_{2} \mathrm{O}_{2}\right]=5 \mathrm{mM}\right)$ and chalcopyrite ((B), applied potential $\left.-0.4 \mathrm{~V},\left[\mathrm{H}_{2} \mathrm{O}_{2}\right]=5 \mathrm{mM}\right)$. 

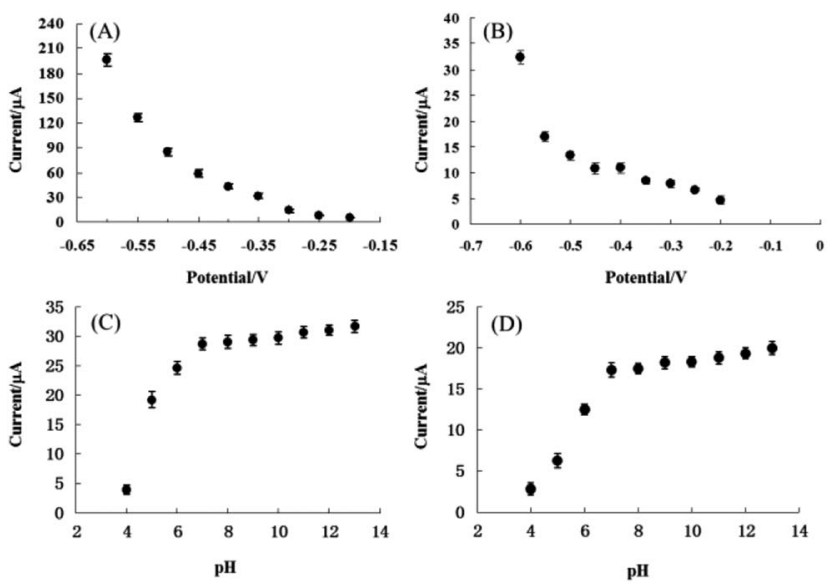

Fig. 5 (A) Effect of applied potential on the amperometric response of pyrite in the presence of $10 \mathrm{mM} \mathrm{H}_{2} \mathrm{O}_{2}$ in $0.1 \mathrm{M} \mathrm{NaOH}$. (B) Effect of applied potential on the amperometric response of chalcopyrite in the presence of $10 \mathrm{mM} \mathrm{H}_{2} \mathrm{O}_{2}$ in $0.1 \mathrm{M} \mathrm{NaOH}$. (C) Effect of $\mathrm{pH}$ on the amperometric response of pyrite in the presence of $10 \mathrm{mM} \mathrm{H}_{2} \mathrm{O}_{2}$, applied potential $-0.4 \mathrm{~V}$. (D) Effect of $\mathrm{pH}$ on the amperometric response of chalcopyrite in the presence of $10 \mathrm{mM} \mathrm{H}_{2} \mathrm{O}_{2}$, applied potential $-0.4 \mathrm{~V}$.

potential and the pH dependency of electrolyte were varied in aqueous solutions with $10 \mathrm{mM} \mathrm{H}_{2} \mathrm{O}_{2}$. The response currents were measured as a function of applied potentials between
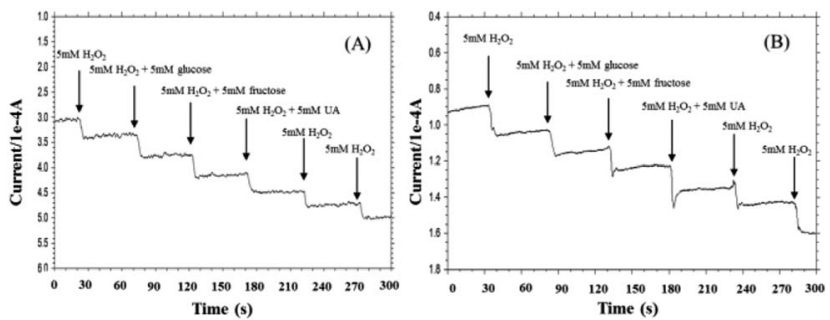

Fig. 6 Amperometric responses of the pyrite (A) and chalcopyrite (B) electrodes for the successive additions of $5 \mathrm{mM} \mathrm{H}_{2} \mathrm{O}_{2}$, the mixture of $5 \mathrm{mM} \mathrm{H}_{2} \mathrm{O}_{2}$ and glucose, the mixture of $5 \mathrm{mM} \mathrm{H}_{2} \mathrm{O}_{2}$ and fructose, the mixture of $5 \mathrm{mM} \mathrm{H}_{2} \mathrm{O}_{2}$ and $\mathrm{UA}, 5 \mathrm{mM} \mathrm{H}_{2} \mathrm{O}_{2}$ (current-time response measured in $0.1 \mathrm{M} \mathrm{NaOH}$ at $-0.6 \mathrm{~V}$ ).
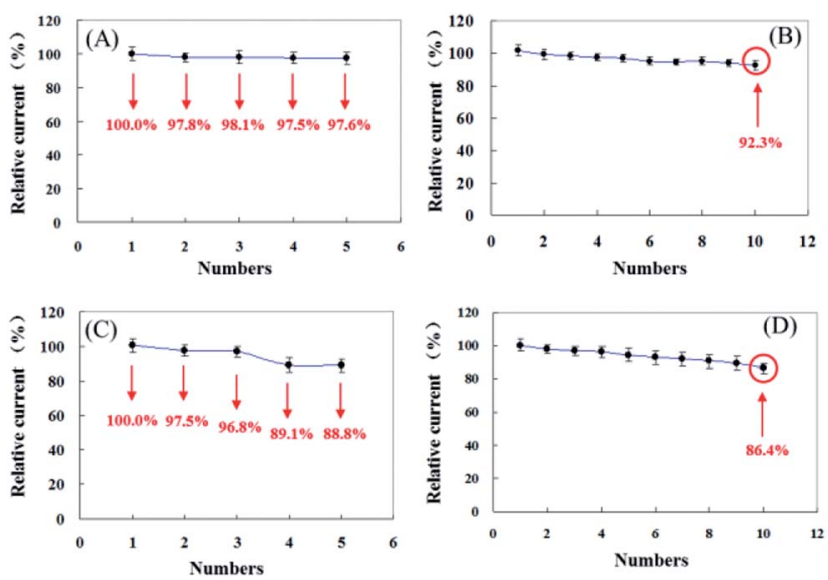

Fig. 7 The reproducibility and repeatability of pyrite (A, B) and chalcopyrite (C, D).
$-0.2 \mathrm{~V}$ and $-0.6 \mathrm{~V}$ with a step of $0.05 \mathrm{~V}$ and the results are shown in Fig. 5A and B for pyrite and chalcopyrite sensors, respectively. The reduction current of $\mathrm{H}_{2} \mathrm{O}_{2}$ increased consistently with decreasing the applied potential. Because the baseline also increased significantly with decreasing the applied potential, the lower potential value was employed in the subsequent experiments to avoid the reduction of soluble oxygen in solution. The effect on reduction current of $\mathrm{pH}$ from 4 to 13 was also studied and the results are shown in Fig. 5C and $\mathrm{D}$ for pyrite and chalcopyrite, respectively. The amperometric response increased from $\mathrm{pH} 4$ to $\mathrm{pH} 7$, reached a plateau at $\mathrm{pH}$ 7, and maintained essentially constant until pH 13 for both pyrite and chalcopyrite. This wide $\mathrm{pH}$ range is preferred not only for the commercial applications, but also for future study in combination with enzymes. These results show that the $\mathrm{OH}^{-}$ group is not essential for the detection of $\mathrm{H}_{2} \mathrm{O}_{2}$. It should be pointed out that strongly alkaline solution is not desirable either from the viewpoint of sensor's practical applications. The finding is very encouraging for commercial applications of
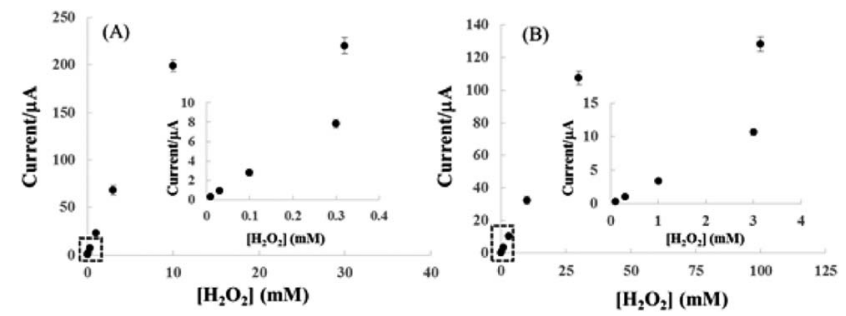

Fig. 8 Calibration plots of $\mathrm{H}_{2} \mathrm{O}_{2}$ obtained with pyrite (A) and chalcopyrite $(B)$ sensors. The insets are enlargement of lower concentration range of the calibration plots of pyrite and chalcopyrite. Applied potential is $-0.6 \mathrm{~V}$ vs. $\mathrm{Ag} / \mathrm{AgCl}$ in $25 \mathrm{mM} \mathrm{NaOH}$ aqueous solution.

Table 2 Comparison between the sensors investigated in this study and other $\mathrm{H}_{2} \mathrm{O}_{2}$ sensors ${ }^{a}$

\begin{tabular}{llll}
\hline & $\begin{array}{l}\text { Linear range } \\
\left(\mathrm{mol} \mathrm{L}^{-1}\right)\end{array}$ & $\begin{array}{l}\text { LOD } \\
\left(\mu \mathrm{mol} \mathrm{L}^{-1}\right)\end{array}$ & Reference \\
\hline $\mathrm{HRP} / \mathrm{SGCCN} / \mathrm{GCE}$ & $5.0 \times 10^{-4}$ to $1.0 \times 10^{-2}$ & 12.89 & 51 \\
$\mathrm{HRP} / \mathrm{sol}-\mathrm{gel} /$ & $7.0 \times 10^{-5}$ to $3.0 \times 10^{-3}$ & 14 & 52 \\
$\mathrm{MWCNT/GCE}$ & & & \\
$\mathrm{GO}-\mathrm{Ag}$ & $1.0 \times 10^{-4}$ to $1.1 \times 10^{-3}$ & 28.3 & 53 \\
nanocomposite & & & \\
nanoCoPc-Gr & $1.0 \times 10^{-5}$ to $6.0 \times 10^{-4}$ & 10.1 & 54 \\
$\mathrm{Cu}_{2} \mathrm{O} / \mathrm{Au}$ & $2.5 \times 10^{-7}$ to $5.0 \times 10^{-3}$ & 0.12 & 55 \\
$\mathrm{CuNi} / \mathrm{MWCNT} /$ & $1.0 \times 10^{-7}$ to $5.0 \times 10^{-3}$ & 0.0025 & 56 \\
$\mathrm{GCE}$ & & & \\
U-CuNWs & $5.0 \times 10^{-7}$ to $8.0 \times 10^{-4}$ & 0.4 & 57 \\
pTB-HRP-GOx/ & $-3.0 \times 10^{-5}$ & 0.2 & 58
\end{tabular}

RGO

Pyrite

$1.0 \times 10^{-5}$ to $1.0 \times 10^{-2} 8.6$

This work

Chalcopyrite

$1.0 \times 10^{-4}$ to $3.0 \times 10^{-2} 52$

This work

${ }^{a}$ SGCCN sol-gel-derived ceramic-carbon nanotube, GCE glass carbon electrode, MWCNT multiwalled carbon nanotubes, GO graphene oxide, nanoCoPc cobalt phthalocyanine nanorods $\mathrm{Gr}$ graphene, $\mathrm{Cu}_{2} \mathrm{O}$ cuprous oxide nanowires, CuNi copper/nickel, u-CuNWs vertically aligned copper nanowires, pTB-HRP-GOx/RGO poly(toluidine blue)horseradish peroxidase-glucose oxidase/reduced graphene oxide. 
Table 3 Pyrite and chalcopyrite sensors applied to drinking water and $\mathrm{H}_{2} \mathrm{O}_{2}$ in disinfector samples

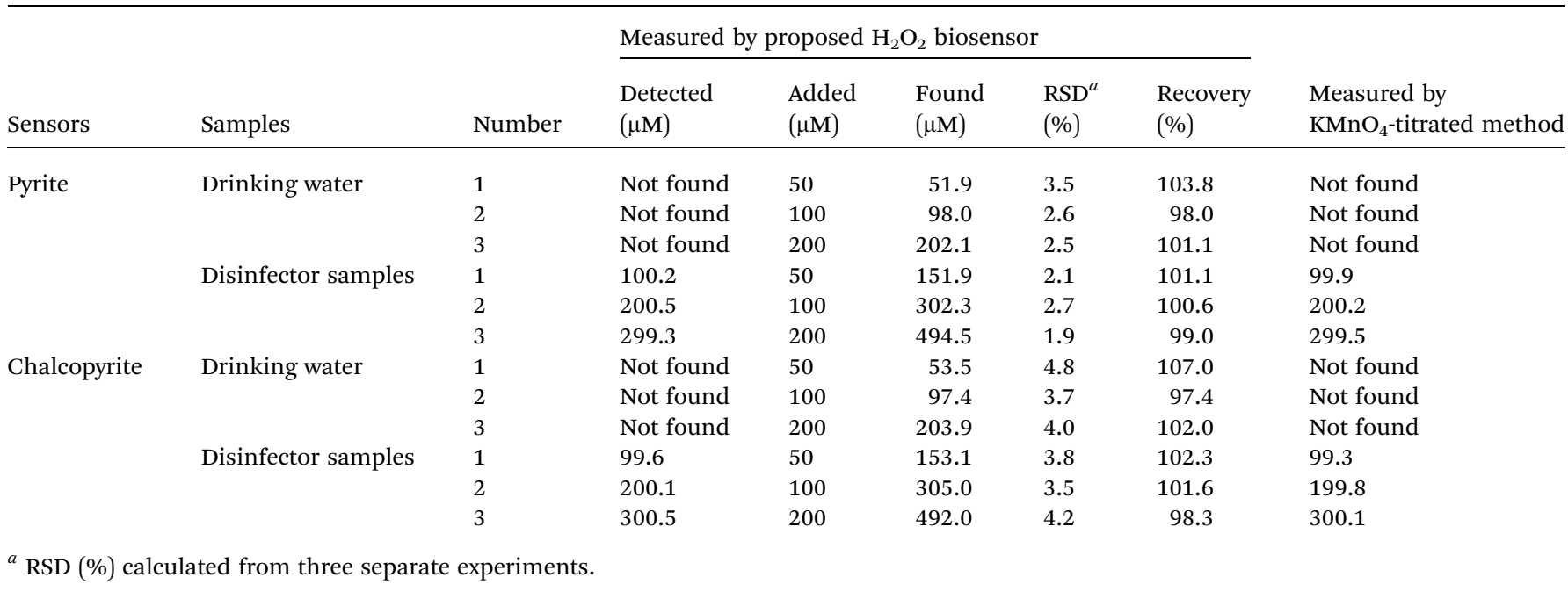

mineral sensors in complicated environment although the operational stability is not satisfying in the neutral and acid conditions with the current design of electrodes and refinement in electrode fabrication is needed for better sensing performance.

Selectivity is another important parameter for nonenzymatic $\mathrm{H}_{2} \mathrm{O}_{2}$ sensor since a good selectivity ensures high accuracy. ${ }^{46}$ To investigate the selectivity of pyrite and chalcopyrite for $\mathrm{H}_{2} \mathrm{O}_{2}$, the effect of interfering reagents on the response current has been studied. The typical amperometric response on successive additions of $5 \mathrm{mM} \mathrm{H}_{2} \mathrm{O}_{2}$, and $5 \mathrm{mM}$ interference species (UA, glucose, fructose) under stirring is shown in Fig. 6. It is important to minimize the effect of interfering species possibly existing in real aqueous solutions for practical applications of amperometric sensors. As shown in Fig. 6, a clear current step was observed with the addition of $\mathrm{H}_{2} \mathrm{O}_{2}$ and negligible effects on the current response were observed when glucose, fructose and UA were added into the solution, demonstrating that the natural minerals can be used to detect $\mathrm{H}_{2} \mathrm{O}_{2}$ in the presence of these interferents at the same concentration. The results seemed acceptable in comparison with conventional $\mathrm{H}_{2} \mathrm{O}_{2}$-detected biosensors. ${ }^{47-49}$ The good antiinterference ability may largely be attributed to the low working potential used in the determination of $\mathrm{H}_{2} \mathrm{O}_{2} \cdot{ }^{\mathbf{5 0}}$

The repeatability and reproducibility of pyrite and chalcopyrite sensors were examined by detecting $5 \mathrm{mM} \mathrm{H}_{2} \mathrm{O}_{2}$ five times with an interval of 24 hours and the results are shown in Fig. 7. In comparison pyrite shows better repeatability and reproducibility than chalcopyrite sensor. The relative standard deviation (RSD) of repeatability and reproducibility is $2.77 \%$ and $0.95 \%$ for pyrite and $4.27 \%$ and $4.98 \%$ for chalcopyrite, which represent very good performance, especially for natural mineral sensors.

Fig. 8 shows the correlation between cathodic peak current and $\mathrm{H}_{2} \mathrm{O}_{2}$ concentration for pyrite (A) and chalcopyrite (B) electrode in $25 \mathrm{mM} \mathrm{NaOH}$ aqueous solution at the applied potential of $-0.6 \mathrm{~V}$. The pyrite and chalcopyrite sensors show a wide range of linear relationship between the response current and $\mathrm{H}_{2} \mathrm{O}_{2}$ concentration from $1.0 \times 10^{-5} \mathrm{~mol} \mathrm{~L}^{-1}$ to 1.0 $\times 10^{-2} \mathrm{~mol} \mathrm{~L}^{-1}$ with a correlation coefficient of 0.997 and from $1.0 \times 10^{-4} \mathrm{~mol} \mathrm{~L}^{-1}$ to $3.0 \times 10^{-2} \mathrm{~mol} \mathrm{~L}^{-1}$ with a correlation coefficient of 0.991 for pyrite and chalcopyrite, respectively. The limit of detection (LOD) was as low as $8.6 \times 10^{-6} \mathrm{~mol} \mathrm{~L}^{-1}$, with a sensitivity of $19.61 \mu \mathrm{A} \mathrm{mM}{ }^{-1}$ for pyrite $(\mathrm{S} / \mathrm{N}=3)$ whereas the LOD was $5.2 \times 10^{-5} \mathrm{~mol} \mathrm{~L}^{-1}$ with a sensitivity of $3.21 \mu \mathrm{AmM}^{-1}$ for chalcopyrite $(\mathrm{S} / \mathrm{N}=3)$. In comparison with other $\mathrm{H}_{2} \mathrm{O}_{2}$-based sensors including enzyme and non-enzyme system shown in Table 2, the characteristics of pyrite and chalcopyrite sensors were rather impressive, especially considering the natural minerals were directly used without any purification. Although certain nanomaterial modified electrodes possess better performance but they are much more costly and require a complex fabrication process.

To further investigate the selectivity and applicability of pyrite and chalcopyrite towards $\mathrm{H}_{2} \mathrm{O}_{2}$, disinfector samples and drinking water were used as real samples. The results are presented in Table 3 . The results were consistent with the conventional potassium permanganate titration method. ${ }^{59}$ RSD and recovery were less than $3.5 \%$ and $98.0-103.8 \%$, respectively for pyrite sensor and less than $4.8 \%$ and $97.4-107.0 \%$ for chalcopyrite sensor, suggesting that both pyrite and chalcopyrite can be used to detect and measure the concentration of $\mathrm{H}_{2} \mathrm{O}_{2}$ in real samples with reasonably good performance.

\section{Conclusions}

Electrochemical characteristics of the solid-state amperometric sensors based on the natural sulfide minerals of pyrite and chalcopyrite are investigated in aqueous medium. The electrodes were conveniently prepared using inexpensive natural sulfide minerals that originated from the natural environment. In $25 \mathrm{mM} \mathrm{NaOH}$ solution at $-0.6 \mathrm{~V}$ (vs. $\mathrm{Ag} / \mathrm{AgCl})$ the pyrite electrode and chalcopyrite electrode displayed a current response that is in linear relationship with $\mathrm{H}_{2} \mathrm{O}_{2}$ concentration 
in a wide range from $1.0 \times 10^{-5} \mathrm{~mol} \mathrm{~L}^{-1}$ to $1.0 \times 10^{-2} \mathrm{~mol} \mathrm{~L}^{-1}$ and $1.0 \times 10^{-4} \mathrm{~mol} \mathrm{~L}^{-1}$ to $3.0 \times 10^{-2} \mathrm{~mol} \mathrm{~L}^{-1}$, respectively. Moreover, the sulfide mineral electrodes exhibited good repeatability and rapid response time (about 3-4 s). The pyrite and chalcopyrite can be used over a wide $\mathrm{pH}$ range. Based on this study, it is believed that other sulfide minerals may also work as the sensor for the detection of $\mathrm{H}_{2} \mathrm{O}_{2}$. Future studies will be focused on practical usage of natural sulfide minerals as sensitive electrochemical amperometric sensors in aqueous and non-aqueous solution for detection and concentration measurements of some chemical compounds important for pharmaceutical and environmental applications.

\section{Conflicts of interest}

There are no conflicts to declare.

\section{Acknowledgements}

The authors gratefully acknowledge the financial support from the Natural Science Foundation of Liaoning Province (No. 20170540464), the Department of Education of Liaoning (No. 2017LNQN05) and the Foundation of University of Science and Technology, Liaoning (No. 2015QN08 and No. 2016RC12). We would like to express our grateful appreciation to Dr X. X. Gao of University of Science and Technology Liaoning for her assistance in XRF analyses.

\section{References}

1 B. Halliwella, M. V. Clementb and L. H. Longvsdfa, FEBS Lett., 2000, 486, 10.

2 T. Ruzgas, E. Csöregi, J. Emneus, L. Gorton and G. MarkoVarga, Anal. Chim. Acta, 1996, 330, 123.

3 C. Matsubara, N. Kawamoto and K. Takamura, Analyst, 1992, 117, 1781.

4 N. V. Klassen, D. Marchington and C. E. McGowan, Anal. Chem., 1994, 66, 2921.

5 M. Giorgetti, D. Tonelli, M. Berrettoni, G. Aquilanti and M. Minicucci, J. Solid State Electrochem., 2014, 18, 965.

6 S. Hanaoka, J. M. Lin and M. Yamada, Anal. Chim. Acta, 2001, 426, 57.

7 T. R. Holm, G. K. George and M. J. Barcelona, Anal. Chem., 1987, 59, 582.

8 H. Razmi and R. Mohammad-Rezaei, Microchim. Acta, 2010, 171, 257.

9 L. Y. Ning, Y. Z. Liu, J. W. Ma, X. B. Fan, G. L. Zhang, F. B. Zhang, W. C. Peng and Y. Li, Ind. Eng. Chem. Res., 2017, 56, 4327.

10 Y. Y. Zhang, X. Y. Bai, X. M. Wang, K. K. Shi, Y. L. Zhu and H. Jiang, Anal. Chem., 2014, 86, 9459.

11 Y. Wang and Y. Hasebe, Sens. Actuators, B, 2011, 155, 722.

12 F. Ricci and G. Palleschi, Biosens. Bioelectron., 2005, 21, 389.

13 D. Y. Tang, B. Y. Xia and Y. Q. Zhang, Microchim. Acta, 2008, 160, 367.

14 H. L. Zhang, G. S. Lai, D. Y. Han and A. M. Yu, Anal. Bioanal. Chem., 2008, 390, 971.
15 Y. Xiao, H. X. Ju and H. Y. Chen, Anal. Chim. Acta, 1999, 391, 73.

16 C. X. Lei, S. Q. Hu, G. L. Shen and R. Q. Yu, Talanta, 2003, 59, 981.

17 J. F. Ping, S. P. Ru, K. Fan, J. Wu and Y. B. Ying, Microchim. Acta, 2010, 171, 117.

18 J. Y. Jin, W. Q. Wu, H. Min, H. M. Wu, S. F. Wang, Y. Ding and S. J. Yang, Microchim. Acta, 2017, 184, 1389.

19 R. J. Toh, C. C. Mayorga-Martinez, J. Han, Z. Sofer and M. Pumera, Anal. Chem., 2017, 89, 4978.

20 X. H. Shu, Y. Chen, H. Y. Yuan, S. F. Gao and D. Xiao, Anal. Chem., 2007, 79, 3695.

21 F. A. Wang, X. Q. Liu, C. H. Lu and I. Willner, ACS Nano, 2013, 7, 7278.

22 Z. Zhang, S. Q. Gu, Y. P. Ding, F. F. Zhang and J. D. Jin, Microchim. Acta, 2013, 180, 1043.

23 V. S. Joshi, J. Kreth and D. Koley, Anal. Chem., 2017, 89, 7709. 24 H. Wei, J. D. Xie, X. M. Jiang, T. Ye, A. P. Chang and W. T. Wu, Macromolecules, 2014, 47, 6067.

25 F. Doroftei, T. Pinteala and A. Arvinte, Microchim. Acta, 2014, 181, 111.

26 K. Thenmozhi and S. Sriman Narayanan, Anal. Bioanal. Chem., 2007, 387, 1075.

27 D. R. Shankaran, N. Uehera and T. Kato, Anal. Bioanal. Chem., 2002, 374, 412.

28 E. Ahlberg, K. S. E. Forssberg and X. Wang, J. Appl. Electrochem., 1990, 20, 1033.

29 Y. Y. Huai, C. Plackowski and Y. J. Peng, Miner. Eng., 2017, 111, 131.

30 D. P. Tao, P. E. Richardson, G. H. Luttrell and R. H. Yoon, Electrochim. Acta, 2003, 48, 3615.

31 A. P. Chandra and A. R. Gerson, Surf. Sci. Rep., 2010, 65, 293.

32 N. P. Finkelstein, Int. J. Miner. Process., 1997, 52, 81.

33 Z. Simić, Z. Stanić and M. Antonijević, J. Braz. Chem. Soc., 2011, 22, 709.

34 R. Mihajlović, Z. Stanić and M. Antonijević, Electrochim. Acta, 2006, 51, 3707.

35 Z. Stanić and J. Stepanović, Monatsh. Chem., 2010, 141, 137. 36 Z. Stanić and J. Stepanović, J. Solid State Electrochem., 2016, 20, 2879.

37 P. K. Abraitis, R. A. D. Pattrick and D. J. Vaughan, Int. J. Miner. Process., 2004, 74, 41.

38 X. Zhu, M. E. Wadsworth, D. M. Bodily and A. M. Riley, Processing and Utilization of High Sulfur Coals IV, Elsevier, Amsterdam, 1991, pp. 205-222.

39 Y. Wang and Y. Hasebe, Anal. Sci., 2011, 27, 401.

40 H. Y. Song, C. H. Ma, L. Y. You, Z. Y. Cheng, X. H. Zhang, B. S. Yin, Y. N. Ni and K. Q. Zhang, Microchim. Acta, 2015, 182, 1543.

41 Y. Wang, T. Hosono and Y. Hasebe, Microchim. Acta, 2013, 180, 1295.

42 K. Thenmozhi and S. S. Narayanan, Anal. Bioanal. Chem., 2007, 387, 1075.

43 J. B. Jia, Microchim. Acta, 2008, 163, 237.

44 G. S. Lai, H. L. Zhang and D. Y. Han, Microchim. Acta, 2009, 165, 159. 
45 H. J. Jiang, C. Du, Z. Q. Zou, X. W. Li, D. L. Akin and H. Yang, J. Solid State Electrochem., 2009, 13, 791.

46 L. Y. Chen, T. Fujita, Y. Ding and M. W. Chen, Adv. Funct. Mater., 2010, 20(14), 2279.

47 J. F. Ping, S. P. Ru, K. Fan, J. Wu and Y. B. Ying, Microchim. Acta, 2010, 171, 117.

48 H. A. Zhong, R. Yuan and Y. Q. Chai, Bioprocess Biosyst. Eng., 2011, 34(8), 923.

49 L. Q. Luo, L. M. Zhu, Y. H. Xu, L. Y. Shen, X. Wang, Y. P. Ding, Q. X. Li and D. M. Deng, Microchim. Acta, 2011, 174, 55.

50 F. Chekin, L. Gorton and I. Tapsobea, Anal. Bioanal. Chem., 2015, 407, 439.

51 X. H. Kang, J. Wang, Z. W. Tang, H. Wu and Y. H. Lin, Talanta, 2009, 78, 120.

52 S. X. Xu, J. L. Li, Z. L. Zhou and C. X. Zhang, Anal. Methods, 2014, 6, 6310.
53 M. M. Shahid, P. Rameshkumar and N. M. Huang, Microchim. Acta, 2016, 183, 911.

54 H. H. Wang, Y. Bu, W. L. Dai, K. Li, H. D. Wang and X. Zuo, Sens. Actuators, B, 2015, 216, 298.

55 Z. K. Yan, J. W. Zhao, L. R. Qin, F. Mu, P. Wang and X. N. Feng, Microchim. Acta, 2013, 180, 145.

56 W. Yi, J. Liu, H. B. Chen, Y. Gao and H. M. Li, J. Solid State Electrochem., 2015, 19, 1511.

57 L. G. Carmona, M. M. Guzmán, A. Martín, S. B. Martínez, A. B. F. Martínez, M. C. González, J. L. Cazaña and A. Escarpa, Biosens. Bioelectron., 2017, 96, 146.

58 F. Wang, W. C. Gong, L. L. Wang and Z. L. Chen, Microchim. Acta, 2015, 182, 1949.

59 L. M. Li, Z. F. Du, S. Liu, Q. Y. Hao, Y. G. Wang, Q. H. Li and T. H. Wang, Talanta, 2010, 82, 1637. 